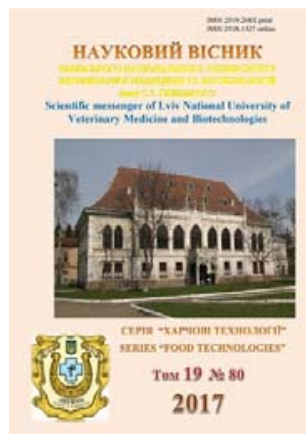

Науковий вісник Львівського національного університету ветеринарної медицини та біотехнологій імені С.3. Гжицького

Scientific Messenger of Lviv National University of Veterinary Medicine and Biotechnologies

doi:10.15421/nvlvet8006

ISSN 2519-268X print

ISSN 2518-1327 online

http://nvlvet.com.ua/

УДК 621.37:637.142.

\title{
Вплив імпульсних електричних полів на мікробіологічні показники та вміст вітаміну С в незбираному молоці
}

\author{
Р.С. Святненко ${ }^{1}$, А.І. Маринін ${ }^{1}$, А.В. Макогон ${ }^{2}$, О.П. Фурсік ${ }^{1}$ \\ Svyatnenko@i.ua, andrii_marynin@ukr.net \\ ${ }^{1}$ Національний університет харчових технологій, \\ вул. Володимирська, 68, м. Київ, 01601, Украӥна; \\ ${ }^{2}$ Національний технічний університет «Харківський політехнічний інститут», \\ вул. Кирпичова, 2, Харків, 61002, Україна
}

\begin{abstract}
Стаття присвячена проблемі зберігання бактеріологічної чистоти та вмісту вітаміну С в незбираному молочі при оброблені сильними імпульсними електричними полями. Відомо, що важливим показником мікробіологічної безпечності та якості, а також рівня санітарно-гігієнічних умов обробки молока є мікробіологічні показники (КМАФАнМ) та (БГКП). При перевищенні допустимого титру мікроорганізми КМАФАнМ та БГКП можуть спричиняти псування готового продукту $i$ навіть харчові отруєння. Об'єкт дослідження: імпульсні електричні поля. Предмет дослідження: незбиране молоко до та після оброблення імпульсними електричними полями. Оброблення незбираного молока здійснювали на експериментальній установиі, щзо складається з трансформатора, іскрових розрядників, ємнісних нагромаджувачів енергії, системи керування, робочої камери. Наявність чисельності КМАФАнМ та БГКП в обробленому молочі визначали шляхом посіву на живильні середовища. Масову частку вітаміну С визначали титриметричним методом. При дослідженнях встановлено, щчо обробка сильними електричними полями з напругою $30 \mathrm{\kappa B} / \mathrm{cм}$ протягом 30 с є найбільш ефективною, оскільки спостерігається повна інактивачія мікроорганізмів КМАФАнМ та БГКП. Доведено можливість здійснення теплового оброблення незбираного молока за рахунок нетеплових ефектів, щзо виникають за імпульсної дї електричних полів. Відкрито перспективи використання вітчизняних ІЕП-установок при первинному обробленні незбираного молока з метою поліпшення мікробіологічних показників.
\end{abstract}

Ключові слова: сильне імпульсне електричне поле, незбиране молоко, вітамін С, мікробіологічні показники.

\section{Влияние импульсных электрических полей на микробиологические показатели и содержание витамина С в цельном молоке}

\author{
Р.С. Святненко ${ }^{1}$, А.И. Маринин ${ }^{1}$, А.В. Макогон ${ }^{2}$, О.П. Фурсик ${ }^{1}$ \\ Svyatnenko@i.ua, andrii_marynin@ukr.net \\ ${ }^{1}$ Национальный университет пищевых технологий, \\ ул. Владимирская, 68, г. Киев, 01601, Украина; \\ ${ }^{2}$ Наииональный технический университет «Харьковский политехнический институт», \\ ул. Кирпичева, 2, Харьков, 61002, Украина
}

\begin{abstract}
Статья посвящена проблеме хранения бактериологической чистоты и содержания витамина С в цельном молоке при обработке сильными импульсными электрическими полями. Известно, что важным показателем микробиологической безопасности и качества, а также уровня санитарно-гигиенических условий обработки молока являются микробиологические показатели (КМАФАнМ) и (БГКП). При превышении допустимого титра микроорганизмы КМАФАнМ и БГКП могут вызывать порчу готового продукта и даже пищевые отравления. Объект исследования: импульсные электрические поля. Предмет исследования: цельное молоко до и после обработки импульсными электрическими полями. Обработку цельного
\end{abstract}

Citation:

Kitchenko, L.M. (2017). Improvement of small hard cheese technology aimed at production in minor cheese-making enterprises. Scientific Messenger LNUVMB, 19(80), 29-32. 
молока проводили на экспериментальной установке, состоящей из трансформатора, искровых разрядников, емкостньх накопителей энергии, системы управления, рабочей камеры. Наличие численности КМАФАнМ и БГКП в обработанном молоке определяли путем посева на питательные среды. Массовую долю витамина С определяли титриметрическим методом. При исследованиях установлено, что обработка сильными электрическими полями с напряжением 30 кВ см в течение 30 является наиболее эффективной, поскольку наблюдается полная инактивация микроорганизмов КМАФАнМ и БГКП. Доказана возможность осущчествления тепловой обработки ичельного молока за счет нетепловых эффектов, возникающих при импульсном действии электрических полей. Открыто перспективы использования отечественных ИЕП-установок при первичной обработке ичельного молока с иелью улучшения микробиологических показателей.

Ключевые слова: импульсные электромагнитные поля, цельное молоко, органолептические показатели.

\title{
Influence of pulsed electric fields on microbiological indices and content of vitamin $C$ in whole milk
}

\author{
R. Svyatnenko ${ }^{1}$, A. Marynin ${ }^{1}$, A. Makogon ${ }^{1}$, O. Fursik ${ }^{1}$ \\ Svyatnenko@i.ua, andrii_marynin@ukr.net \\ ${ }^{I}$ National University of Food Technologies, \\ Volodymyrska Str., 68, Kyiv, 01601, Ukraine; \\ ${ }^{2}$ National Technical University «Kharkiv Polytechnic Institute», \\ Kyrpychova Str., 2, Kharkiv, 61002, Ukraine
}

\begin{abstract}
The article is devoted to the problem of bacteriological purity storage and vitamin $C$ content in whole milk by treating with strong pulsed electric fields. It is known that microbiological indices (QMAFAnM) and (CGP) are an important indicator of microbiological safety and quality, as well as the level of sanitary-hygienic conditions of milk processing. By exceeding the permissible titer the microorganisms of QMAFAnM and CGB can cause damage to the finished product and even food poisoning. Object of investigation: pulsed electric fields. Subject of the study: whole milk before and after treatment with pulsed electric fields. Whole milk treatments were carried out in an experimental setup consisting of a transformer, spark gaps, capacitive energy storage devices, a control system and working chamber. The presence of QMAFAnM and CGB in the treated milk was determined by inoculation on nutrient media. The mass fraction of vitamin $C$ was determined by titrimetric method. During the research it was found that processing with strong electric fields in voltage of $30 \mathrm{kV} / \mathrm{cm}$ during the $30 \mathrm{~s}$ is the most effective, since complete inactivation of microorganisms QMAFAnM and CGB. The possibility of heat treatment of whole milk is proved due to nonthermal effects that occur when the electric fields are pulsed. The prospects of using domestic IEPs for the initial processing of whole milk are opened with the aim of improving microbiological indicators.
\end{abstract}

Key words: strong pulsed electric field, whole milk, vitamin $C$, microbiological indices.

\section{Вступ}

В останні роки для забезпечення необхідної бактеріологічної чистоти в технології молочних продуктів все частіше почали використовувати більш жорсткі режими пастеризації 3 високою температурою $\left(95 \ldots 97^{\circ} \mathrm{C}\right)$, що не тільки підвищують енергозатрати, а й більш суттєво впливають на складові частини молока (особливо білки, вітаміни, кальцій) (Cherniushok et al., 2013).

Перспективним напрямом підвищення бактеріологічної чистоти молока $є$ застосування електрофізичних методів, а саме сильних імпульсних електричних полів (IЕП) без розрядів.

Автори (Sviatnenko et al., 2016) стверджують, що IЕП дозволяє зберігати харчову і біологічну цінність дослідних зразків порівняно з традиційною тепловою пастеризацією, а тим більше високотемпературною стерилізацією.

\section{Матеріал і методи досліджень}

Метою дослідження є вивчення впливу сильних імпульсних електричних полів на мікробіологічні показники та вітамін С незбираного молока.

Молоко є вельми сприятливим живильним середовищем для розвитку багатьох мікроорганізмів. Після вживання в їжу інфікованого молока і молочних про- дуктів можуть виникати такі інфекції, як черевний тиф, дизентерія, холера, ешеріхіози, бруцельоз, туберкульоз, отруєння стафілококових ентеротоксинів та iн. (Kukhtin, 2006).

Визначення наявності мікроорганізмів використовується як індикатор для встановлення мікробіологічної безпечності сировини та харчових продуктів, оскільки їх присутність свідчить про рівень дотримання санітарно-гігієнічних вимог у ході виробничих процесів.

При проведенні досліджень використовувалася експериментальна установка, яка розроблена фахівцями в НТУ «Харківський Політехнічний Інститут» (Bojko, 2001), зображена на рис. 1.

Дослідні зразки готували шляхом обробки незбиране молоко $з$ початковою температурою $(22 \pm 2){ }^{\circ} \mathrm{C}$ в стаціонарній камері закритого типу. В робочу камеру впродовж 10-30 с здійснювалася подача енергії через іскрові розрядники.

Напругу на робочій камері $з$ оброблюваним продуктом (незбираним молоком) реєстрували цифровим осцилографом фірми Rigol зі смугою пропускання 100 МГц.

Аналіз осцилограми, рис 2, показує, що амплітуда напруги на робочій камері складає $\approx 30$ кВ, напруженість електричного поля в робочій камері (РК) $\approx 20$ кВ/см, а тривалість фронту імпульсу $\approx 35$ нс. 


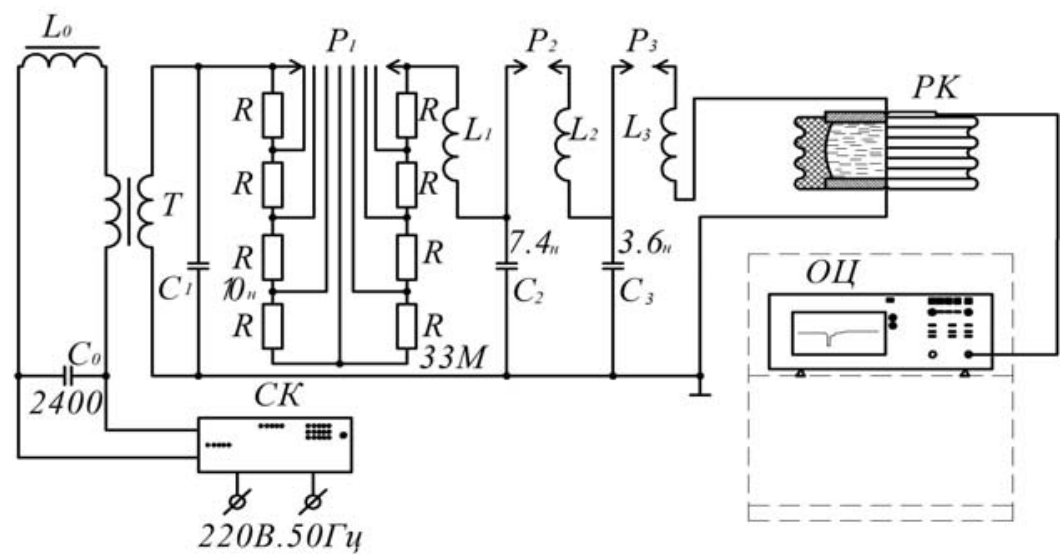

Рис. 1. Схема експериментальної установки для обробки рідких продуктів сильними імпульсними електричними полями

$\mathrm{L}_{\mathrm{o}}$ - дросель на броньовому магнітопроводі з еквівалентним перерізом 100 х 90мм, Т - трансформатор ИОМ-100/100, $\mathrm{L}_{1}-\mathrm{L}_{3}-$

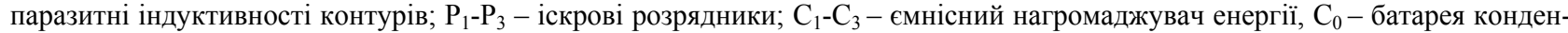
саторів, СК - система керування, СППУР - система підготовки, перекачування і упаковки рідин, ОЦ - осцилограф,РК робоча камера.

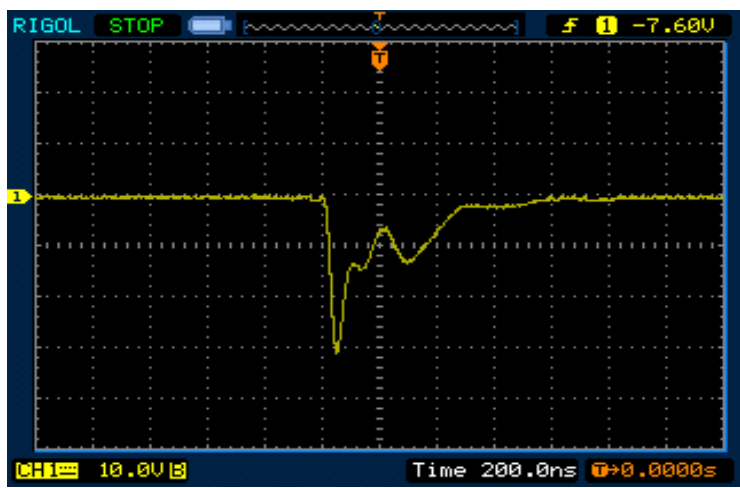

Рис. 2. Типова осцилограма напруги на РК з оброблюваним молоком

Санітарну оцінку молока проводили за двома мікробіологічними показниками: загальне бактеріальне обсіменіння молока (КМАФАнМ) і наявність бактерій групи кишкової палички (БГКП) (GOST 26669-85).

При визначені загального бактеріального обсіменіння використовували універсальні поживні середовища: м'ясо-пептонний агар (МАП) і середовища для визначення (КМАФАнМ) (GOST 10444.15-94).

Масову частку вітаміну С визначали титриметричним методом за ГОСТ 30627.2-8.

\section{Результати та їх обговорення}

Після оброблення незбираного молока в мікробіологічній лабораторії відбувався кількісний підрахунок бактерій, що вижили, за вищеперерахованими методиками.

Результати проведених досліджень 3 вивчення впливу ІЕП на мікробіологічні показники наведено в таблиці 1 та 2.

Таблиия 1

Вплив параметрів сильних імпульсних електричних полів на кількість (КМАФАнМ), КУО в $1 \mathrm{~cm}^{3}$

\begin{tabular}{|c|c|c|c|}
\hline \multirow{2}{*}{ Час оброблення, с } & \multirow{2}{*}{ Контроль } & \multicolumn{2}{|c|}{ Режим обробки } \\
\hline & & $\mathrm{U}=15 \mathrm{\kappa B} / \mathrm{cm}$ & $\mathrm{U}=30 \mathrm{\kappa B} / \mathrm{cm}$ \\
\hline 10 & \multirow{5}{*}{$1 \times 10^{5}$} & $1 \times 10^{3}$ & $1 \times 10^{2}$ \\
\hline 15 & & $1 \times 10^{2}$ & 300 \\
\hline 20 & & 400 & 10 \\
\hline 25 & & 255 & 0 \\
\hline 30 & & 98 & 0 \\
\hline
\end{tabular}

Табличя 2

Вплив параметрів сильних імпульсних електричних полів на кількість (БГКП), КУО в $1 \mathrm{~cm}^{3}$

\begin{tabular}{|c|c|c|c|}
\hline \multirow{2}{*}{ Час оброблення, с } & \multirow{2}{*}{$\begin{array}{l}\text { Контроль } \\
\text { КУО/см }\end{array}$} & \multicolumn{2}{|c|}{ Режим обробки } \\
\hline & & $\mathrm{U}=15 \mathrm{\kappa B} / \mathrm{cm}$ & $\mathrm{U}=30 \mathrm{\kappa B} / \mathrm{cm}$ \\
\hline 10 & \multirow{5}{*}{$1 \times 10^{5}$} & $1 \times 10^{4}$ & $1 \times 10^{3}$ \\
\hline 15 & & $2 \times 10^{3}$ & $1 \times 10^{2}$ \\
\hline 20 & & $1 \times 10^{2}$ & 250 \\
\hline 25 & & 800 & 75 \\
\hline 30 & & 400 & 0 \\
\hline
\end{tabular}


Одержані експериментальні дані показують, що зі збільшенням напруги та тривалості оброблення відбувається істотне зниження кількості мікроорганізмів в усіх зразках. Зниження життєдіяльності мікроорганізмів, на наш погляд, можна пояснити комплексним впливом виникаючих при ІЕП обробці сильних імпульсних електричних полів та нетеплового ефекту зростання температури.

Одним 3 найважливіших вітамінів антиоксидантної системи молока є вітамін С (аскорбінова кислота). Аскорбінова кислота - активний учасник багатьох процесів, що протікають в організмі людини. Вона підвищує стійкість до інфекційних захворювань, збільшує працездатність, позитивно впливає на кровотворення, обмін вуглеводів і холестерину. Однак при високих температурах обробки вона легко окислюється та втрачає свої властивості. В зв'язку з цим нами було вирішено дослідити вплив ІЕП при різних режимах обробки на вміст вітаміну $\mathrm{C}$ в обробленому молоці.

Результати щодо зміни вмісту вітаміну С в обробленому молоці ІЕП представлено в таблиці 3 .

Таблиця 3

Зміна вмісту вітаміну С в обробленому молоці

\begin{tabular}{|c|c|c|c|}
\hline \multirow{2}{*}{ Час оброблення, с } & \multirow{2}{*}{$\begin{array}{l}\text { Контроль, } \\
\text { млн/100 г }\end{array}$} & \multicolumn{2}{|c|}{ Режим обробки } \\
\hline & & $\mathrm{U}=15 \mathrm{\kappa B} / \mathrm{cm}$ & $\mathrm{U}=30 \mathrm{\kappa B} / \mathrm{cm}$ \\
\hline 10 & \multirow{5}{*}{1,80} & 0,90 & 0,79 \\
\hline 15 & & 0,81 & 0,63 \\
\hline 20 & & 0,60 & 0,49 \\
\hline 25 & & 0,58 & 0,42 \\
\hline 30 & & 0,42 & 0,34 \\
\hline
\end{tabular}

Як видно 3 наведених результатів, встановлено зниження відсоткового вмісту вітаміну С. Найбільше зниження спостерігається при обробленні $30 \mathrm{kB} / \mathrm{cm}$ протягом 30 с (0,34 млн/100 г). Найменшого впливу вітамін С зазнав при $15 \mathrm{\kappa B} / \mathrm{cm}$ протягом $10 \mathrm{c}$ (0,90 млн/100 г).

\section{Висновки}

Досліджено вплив сильних імпульсних електричних полів (IЕП) на процес інактивації мікроорганізмів в обробленому молоці. Встановлено оптимальні режими IЕП (високовольтних імпульсів при напрузі 1530 кВ/см). Доведено можливість здійснення теплового оброблення незбираного молока за рахунок нетеплових ефектів, що виникають за імпульсної дії електричних полів.

\section{Бібліографічні посилання}

Cherniushok, O.A., Kochubei-Lytvynenko, O.V., Pukhliak, A.H. (2013). Diia elektrychnykh rozriadiv na mikrobiolohichni pokaznyky syrovatky molochnoi. Kharchova promyslovist. 14, 53-58 (in Ukrainian).
Sviatnenko, R.S., Kochubei-Lytvynenko, O.V., Marynin, A.I. (2016). Vplyv impulsnykh elektrychnykh poliv na sklad i vlastyvosti nezbyranoho moloka. Naukovi pratsi NUKhT. 4, 241-247 (in Ukrainian).

Kukhtin, M.D. (2006). Dynamika mikrobiolohichnoho protsesu mikroflory moloka. Nauk. visnyk Lviv. nats. akademii vet. medytsyny im. S.Z. Hzhytskoho. 8, 2(29), 112-116 (in Ukrainian).

Bojko, N.I. (2001). Vysokovol'tnye apparaty i tehnologii na osnove kompleksa vysokovol'tnyh impul'snyh vozdejstvij. Visnik NTU «HPI». 16, 11-16 (in Russian).

GOST 26669-85. Produkty pishhevye i vkusovye. Podgotovka prob dlja mikrobiologicheskih analizov (in Russian).

GOST 10444.15-94. Produkty pishhevye. Metody opredelenija kolichestva mezofil'n'nyh ajerobnyh i fakul'tativno-anajerobnyh mikroorganizmov (in Russian). 